\title{
The Identification of Rice Varieties Used in Central Sulawesi
}

\author{
Femmi Norfahmi $^{1,}{ }^{*}$, Komalawati Komalawati ${ }^{2}$, Muh. Afif Juradi ${ }^{1}$, Mardiana Mardiana ${ }^{1}$ and \\ F.F Munier ${ }^{1}$ \\ ${ }^{1}$ Central Sulawesi Assessment Institute for Agricultural Technology, Jl. Lasoso No. 62, Biromaru, \\ Central Sulawesi \\ ${ }^{2}$ Central Java Assessment Institure for Agricultural Technology, Jl. Soekarno Hatta KM.26 No.10, \\ Tegalsari, Bergas Lor, Bergas, Sikunir, Kabupaten Semarang, Central Java 50552
}

\begin{abstract}
Central Sulawesi's rice productivity in 2019 was lower compared to that in 2018. One of the problems for the low productivity of paddy in Central Sulawesi is the application of low quality of seeds. Ministry of Agriculture through Central Sulawesi AIAT has introduced a numbers of new high yielding varieties (HYV) to increase rice production and productivity. To support the dissemination of new HYV, it is important to study the rice varieties that mostly used by farmers in Central Sulawesi. The objectives of this study are to identify the rice varieties and the preferred characteristics of rice varieties that farmers usually used in Central Sulawesi. This study used primary and secondary data. Data were analyzed descriptively and presented in tables and graphs. The results show that most farmers in Central Sulawesi use Mekongga, Ciherang, and Cisantana varieties, and local varieties such as Peluncur, Dewi, Ntabone and others. Farmers generally prefer varieties which tend to produce higher yields and resistant to pests and diseases. To maintain the availability of the varieties in Central Sulawesi, it is important to train farmers to become breeders.
\end{abstract}

\section{Introduction}

Rice is still an important commodity for Indonesian people since rice is the main staple food of people in Indonesia. The strategic role of rice as the main staple food could be seen by the ability of rice to replace the local staple foods in various regions in Indonesia, including in the eastern part of Indonesia, one of which is in Central Sulawesi Province. As rice has become the main staple food for people in Central Sulawesi, the rice consumption in Central Sulawesi has increased from 2015 to 2019 [1]. This could be seen by the average per capita calorie consumption per day in urban and rural areas which is over 900 calories from 2015 to 2019 [1]. The high consumption on calorie indicate that demand of rice in Central Sulawesi Province is still high. The high demand of rice could be anticipated if the rice production in Central Sulawesi could also be increased.

However, rice production and productivity in Central Sulawesi in 2019 actually decreased compared to 2018. Rice production in Central Sulawesi in 2018 reached 926.98 million tons

\footnotetext{
* Corresponding author: femmi_norfahmi@yahoo.co.id
} 
with a productivity of 46.05 quintal/ha [1]. In 2019, rice production decreased to 844.90 million tonnes and a productivity of 46.77 quintals/ha [1]. One of the causes of the decline in rice production and productivity was due to low quality of seeds. Meanwhile, seeds are one of the strategic technological innovations that have been produced by the Indonesian Agency for Agricultural Research and Development (IAARD) of the Ministry of Agriculture. Until 2019, there were 97 new high yield varieties (VUB) produced by IAARD through The Agency for Paddy Research (BBPadi) [2]. The VUB developed consists of Inbred Rice (Inpa) and rice hybrids (Hipa) for planting in various land ecosystems (irrigated rice fields, tidal swamps, and dry land). One of the agencies of IAARD in the regions that is mandated to produce and disseminate the new high yielding varieties is Central Sulawesi Assessment Institute for Agricultural Technology (BPTP Sulawesi Tengah/Central Sulawesi AIAT).

To support the government's efforts in disseminating the new high yielding varieties, it is important to firstly identify the rice varieties that mostly used by farmers in Central Sulawesi. By identifying the common rice varieties used by farmers in Central Sulawesi, Central Sulawesi AIAT could determine the types of rice varieties that have a potential to be developed and adopted by farmers in Central Sulawesi. As mentioned by [3], seed is important in the improvement of food security and farm household livelihood, and thus, farmers would adopt or use seed with characteristics suitable to farmers' agro-ecological and socio-economic condition.

\section{Research Methods}

\subsection{Types of Data and Research Time}

This research was conducted in several locations in Sigi Regency, Central Sulawesi Province. The location was determined purposively because it was the location of the 2018 special effort assistance program (UPSUS), and one of the rice production centers. The research was conducted in January-December 2018.

\subsection{Data Processing and Analysis}

The types of data used in this study are secondary and primary data. Primary data was collected by using survey method. The primary data (cross section data) was obtained from interviews with 30 farmer household respondents who owned lowland rice farming in the research location. The primary data collection used structured questions (questionnaire). Respondents of farmer households were determined randomly by using simple random sampling. Secondary data is obtained from previous studies that have been published in various journals and data from related agencies such as the Center for Seed Supervision and Certification (BPSB) and Central Sulawesi Assessment Center for Agricultural Technology (BPTP Sulawesi Tengah). The data and information obtained were analyzed descriptively and presented in table and graphs.

\section{Results and Discussion}

\subsection{Characteristic of Respondents}

The characteristics of the respondent describe the characteristics of sample farmers related to the farming activities they do. The characteristics described are age, land area, education 
level, and farming experience. Respondents in this study were farmers involved in rice UPSUS activities in Sigi Regency. Most of farmer respondents were in the age range between 41 and 60 years $(73.33 \%)$. Meanwhile, there were only 4 farmers in the lower and higher age ranges, or $13.33 \%$ of the total number of respondents. According to [4], farmers with the mean age of 46 years or between 41 and 60 could be categorized as economically active groups. Farmers in this age category tend to be risk takers. This means they are more likely to take the risk of adopting an improved seed technology in rice production [4].

Table 1. Farmer Respondent Characteristics According to Age in Sigi Regency, Central Sulawesi in 2020

\begin{tabular}{|c|c|c|}
\hline Age (year) & Total (Person) & Percentage (\%) \\
\hline $20-40$ & 4 & 13.33 \\
\hline $41-60$ & 22 & 73.33 \\
\hline $61-70$ & 4 & 13.33 \\
\hline Total & 30 & 100.00 \\
\hline
\end{tabular}

According to its level of education, most of farmer respondents or $50 \%$ of farmer respondents have a secondary education level and above (high school and equivalent). With higher levels of farmer education, it is expected that farmers will likely to use high quality seeds. [5], [6], [7] have found that the education of the farmer household is related to the participation of farmers in using improved varieties. [6] found the positive correlation between education and the participation of farmers in improved seed technology. According to [5], by adding one more year of school, the probability of farmers' participation in improved seed technology would be increased by 0.0279 . The Characteristics of respondent farmers based on education level in Sigi Regency, Central Sulawesi Province in 2020 are presented in Table 2 .

Table 2. The Characteristics of Farmer Respondents According to the Education Level in Sigi Regency, Central Sulawesi in 2020

\begin{tabular}{|c|c|c|}
\hline Education Level & Total (Person) & Percentage (\%) \\
\hline Elementary & 8 & 26.67 \\
\hline Junior High & 7 & 23.33 \\
\hline Senior High School & 15 & 50.00 \\
\hline Total & 30 & 100.00 \\
\hline
\end{tabular}

Table 3 shows the characteristics of farmer respondents according to farming experiences. The average farming experiences of farmers in Sigi Province is between 19 and 36 years. In other words, most farmers in Sigi Regency have enough experiences to compare farming performance between using new high yielding varieties and local varieties. Farmers with more experiences have gained more knowledge from working in uncertain production environment, and thus, they could evaluate the technology and decide their adoption on the technology [7]. Therefore, farming experience is related to the ability of farmers to adopt improved rice varieties [8]. The study of [8] has found that farmers with average farming experiences more than 10 years, have adopted faster the improved rice varieties compared to the less than 10 years ones. The study of [5] also found the positive relationships between rice farming experiences of farmers in Ethiopian and the adoption of improved rice seeds. [9] and [7] have found that socio-economic factors, such as education level and farmers' experience influencing the adoption of improved high yielding varieties. [4] found that the age and the level of education of farmers could influence the adoption of improved rice 
production technology in Imo State of Nigeria. Meanwhile, the study of [10] showed the relationships between the age of farm household, the level of education, farming experiences and the adoption of farmers to improved seed technology. Overall, it could be concluded that the socio-economic factors, such as age, the level of education and farming experiences, could influence farmers' adoption to the improved seed technologies. By referring to the charateristics of farmer respondents in Sigi Regency, Central Sulawesi, the farmers in Sigi Regency tend to be a faster adopter. However, the suitability of the improved seed technology introduced to farmers' preferences should be considered.

Table 3. The Characteristics of Farmer Respondents According to Farming Experiences in Sigi Regency, Central Sulawesi in 2020

\begin{tabular}{|c|c|c|}
\hline Farming Experiences (Year) & Number (person) & Percentage (\%) \\
\hline $1-18$ & 12 & 40.00 \\
\hline $19-36$ & 15 & 50.00 \\
\hline $37-50$ & 3 & 10.00 \\
\hline Total & 30 & 100 \\
\hline
\end{tabular}

\subsection{The Identification of Rice Varieties Used by Farmers in Central Sulawesi}

Farmers in Central Sulawesi have been exposed to high yielding varieties or improved seed varieties since 2006. IAARD through Central Sulawesi AIAT has introduced several high yielding varieties such as Ciherang, Mekongga, Ciliwung, and Cisantana. However, these high yielding varieties have faced several problems, namely high intensity of pests and diseases, leveling off production, and inability to adapt to climate changes [11]. To solve these problems, IAARD through the Indonesian Center for Rice Research (Balitpa) has produced new high yielding varieties that are tolerant to biotic and abiotic environmental stresses. There have been 97 new high yielding varieties produced from 2007 to 2019 [2]. These high yielding varieties produced are expected to substitute the older improved varieties and able to overcome the problems.

According to the interview and observation, there are not many farmers applied the recommended technology component such as the utilization of high yielding varieties. One of the reasons for low utilization of high yielding varieties by farmers is the difficulty of accessing the varieties. The high yielding varieties is difficult to access because of the limited seed system or the unavailable seed breeders in the area. On the other hand, new high yielding varieties is important in increasing rice production and rice productivity [9]. [12] through their study on analyzing determinant components of East Java rice surplus have found that the utilization of new high yielding varieties together with other components of Jarwo or UPSUS could help to achieve rice surplus in East Java. The utilization of new high yielding varieties could increase rice productivity by $56 \%$, and the interaction between the utilization of irrigation water, new high yielding varieties and local specific fertilization could increase rice productivity by $75 \%$ [13]. The study of [14] found that new high yielding varieties, such as Inpago 4, Inpari 7, Inpari 9, Inpari 23, Inpari 24, Inpari 26, Inpari 27, and Inpari 28, could increase the growth component value and crop yield component such as number of productive tillers, panicle length, number of grain per panicle, and percentage of grain pithy.

The increasing productivity of farming could increase farmers' income. The study of [15] showed that the impact of the utilization of new high yielding varieties to income could be seen through the $\mathrm{R} / \mathrm{C}$ value. The utilization of Inpari 32 and Inpari 43 could increase the $\mathrm{R} / \mathrm{C}$ value from 2.02 (Mekongga) to 2.18 and 2.29 [15]. The increasing income is important for farmers since they depend on farming to finance their needs on non-agricultural products. Therefore, farmers will be interested in planting new high yielding varieties if the varieties is relatively more profitable compared to other varieties. 
Figure 1 shows the various new high yielding varieties used by farmers in Central Sulawesi. Farmers in Central Sulawesi has used high yielding varieties that has been introduced by Central Sulawesi AIAT. Those high yielding varieties used are Cirehang (70.74 kg), Mekongga (46.24 kg), Cisantana (39.32 kg), Ciliwung (31.87 kg), and Cigeulis $(27.43 \mathrm{~kg})$. Other IAARD's varieties used by farmers in Central Sulawesi are Inpari 30, Inpari 36, Inpari 24, Memberamo, Sintanur, and others that could be seen in Figure 1. Those varieties used by farmers because of its tolerant to dry, immersion and salinity, and could be used to anticipate the impacts of climate change. Inpari 40, Inpago 8 are used because those varieties are tolerant to dry. Inpari 13 is used because the variety is drought tolerant and tolerant to leafhoppers in irrigated rice fields with potential yields of 8.0-9.5 tonnes/ha.

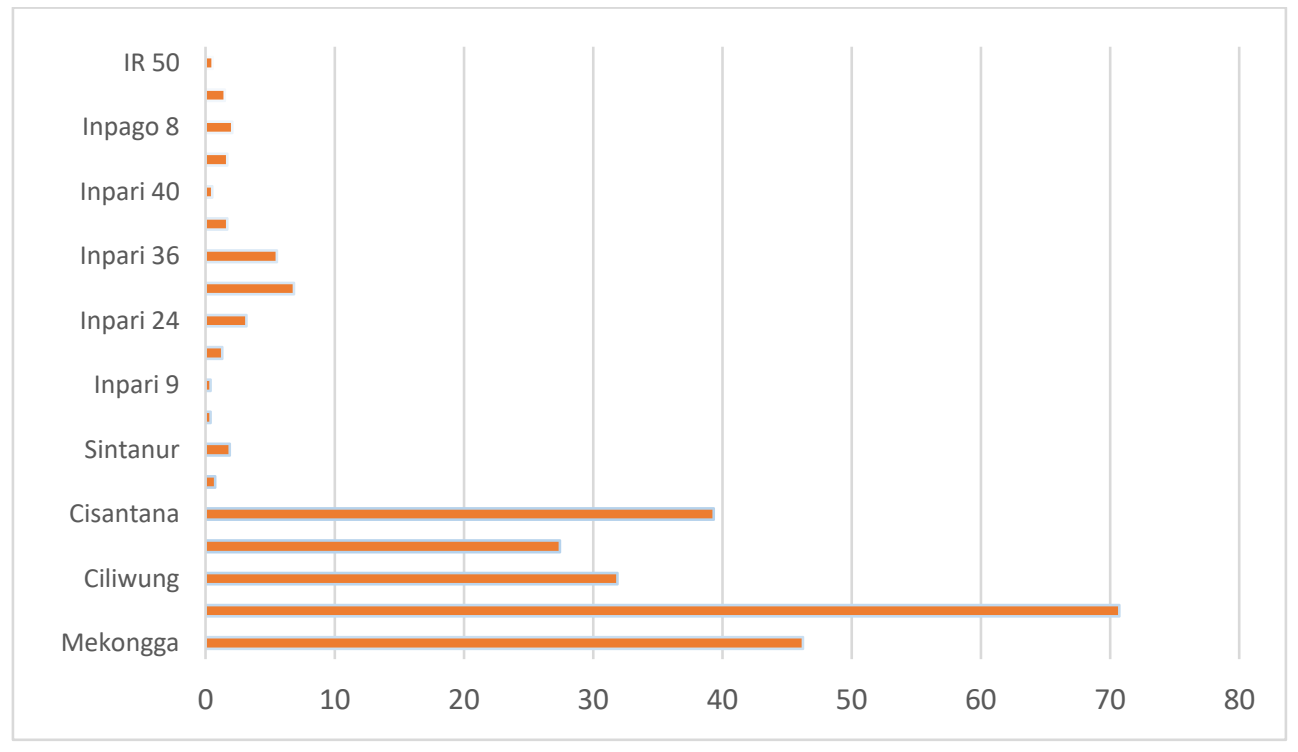

Fig 1. High Yielding Varieties Used by Farmers in Central Sulawesi

Those five highest varieties used by farmers could be seen in Sigi, Banggai, North Morowali (Morut), and Buol (Figure 2). Ciherang as the first highest varieties used could be seen in Toli-Toli, Bangkep, Morowali, and Poso. Mekongga is most favored by farmers in Toli-Toli, Parimo, Donggala, and Sigi, while Cisantana is most preferred by farmers in Tolitoli, North Morowali, and Poso. Therefore, the highest three varieties (Cirehang, Mekongga, Cisantana) have been found in Toli-toli, most sub-districts in Parigi Moutong Regency, while Ciherang and Cisantana are used in all sub-districts in Banggai Islands Regency. In Morowali Regency, every sub-district uses Ciherang variety and the remaining use Ciliwung and Cigeulis varieties. 


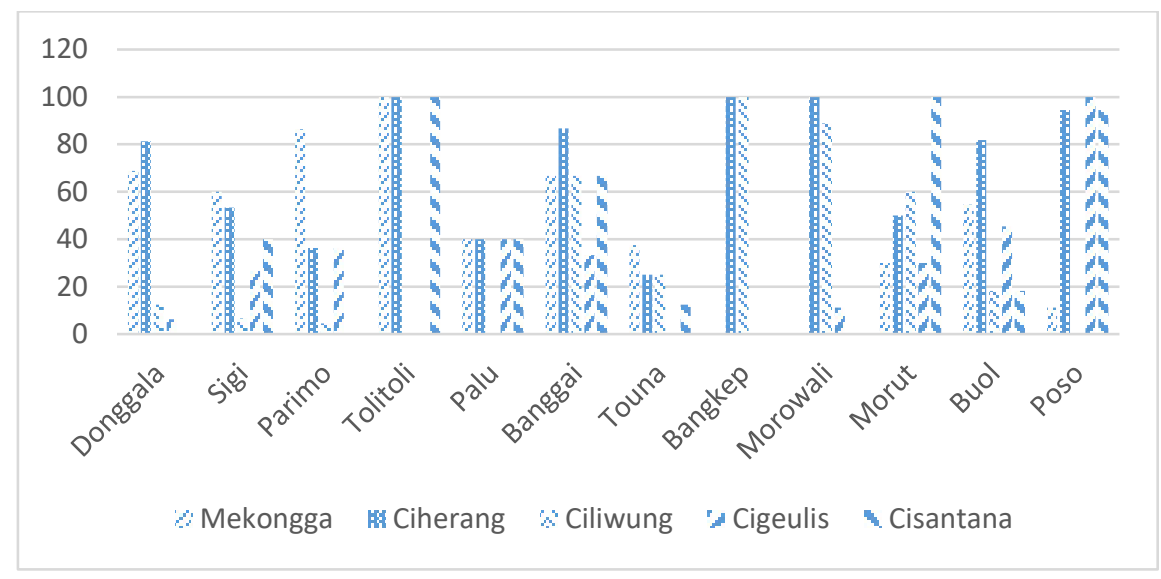

Fig 2. Distribution The Highest Five of New High Yield Varieties Used by Farmers in Central Sulawesi

Figure 3 illustrates the various local varieties used by farmers in Central Sulawesi. There are at least 28 local varieties have been used by farmers in Central Sulawesi. Most farmers in Central Sulawesi use Lombi-lombi, Paresina, Maraya, Tidore, and Pulu Lonu. Local varieties that mostly used were tolerant to drought, as well as tolerant to pest. The characteristics of local varieties used by farmers currently could be an indication that farmers are more likely to use new high yielding varieties with similar characteristics or even better than the local varieties.

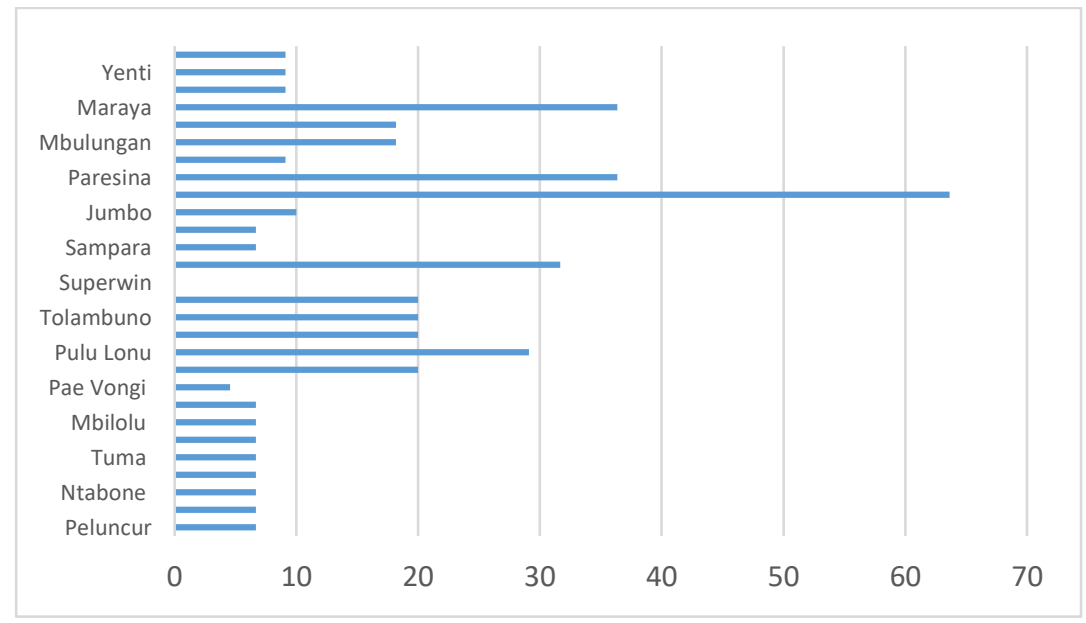

Fig 3. Local Varieties of Rice Used by Farmers in Central Sulawesi

Figure 4 describes the distribution of local varieties in different areas of Central Sulawesi. As could be seen in Figure 4, all local varieties were mostly used in seven regencies of Central Sulawesi. Different area has used different local varieties. Farmers in Sigi Regency used local varieties, namely: peluncur, dewi, Ntabone, Ntilaka, tuma, pumpu, mbilolu, and Tinggaloko that were generally tolerant to drought and pests. The distribution of local varieties in Buol Regency was the largest compared to other areas in Central Sulawesi. Lombi-lombi, Paresina, and Maraya were the most preferred varieties by farmers in Buol District. Farmers like the varieties because those varieties are tolerant to drought and pests. Pae Vongi was only used by farmers in Parigi Mountong (Parimo), while Jumbo was only used in North Morowali (Morut). The remaining varieties were used by farmers in Palu, Banggai, and Toja 
Una (Touna). Different local varieties used by farmers leads to a conclusion that farmers have planted local varieties adjusting to their environment or specific location.

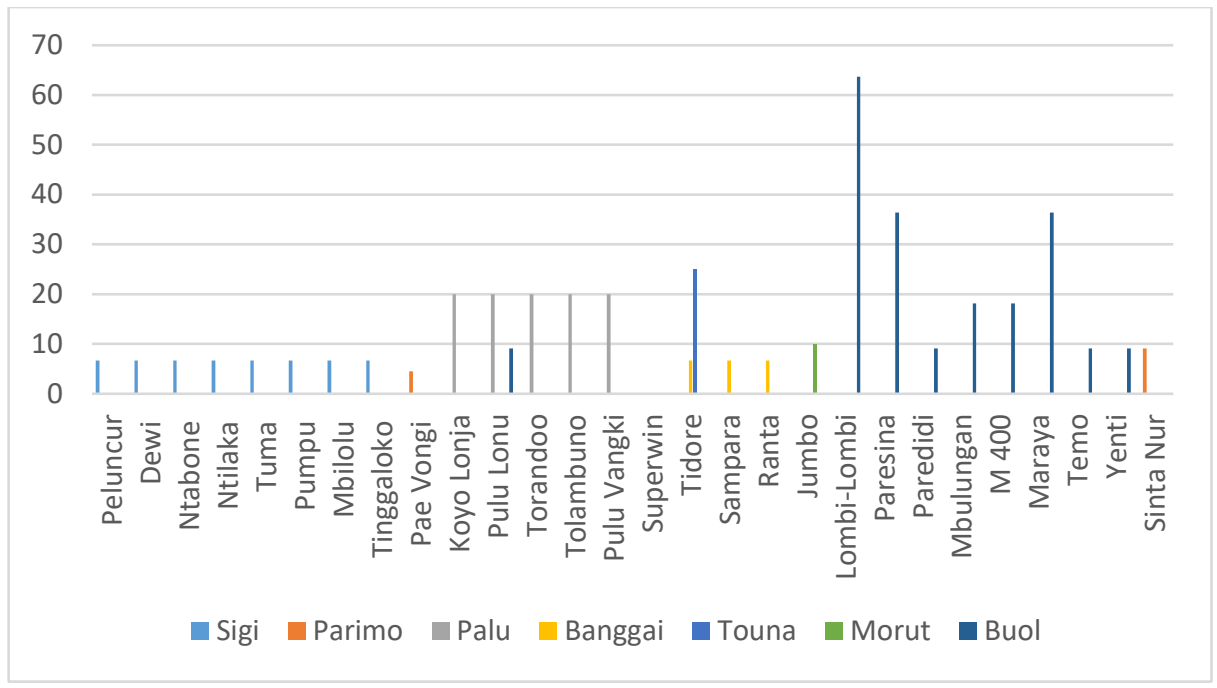

Fig 4. The Distribution of Local Varieties of Rice Used by Farmers in Central Sulawesi

\subsection{Implication}

Farmers in Central Sulawesi has used yielding varieties that have been introduced by IAARD through Central Sulawesi AIAT such as Mekongga, Ciherang, Ciliwung, and Cisantana. This means farmers in Central Sulawesi do not reluctant to adopt the new high yielding varieties if the new varieties introduced could at least have similar characteristics and could produce higher than the older high yielding varieties. This is supported by the socio-economic characteristics of farmers in Sigi Regency that could be categorized as a faster adopter. According to one of the Officers interviewed, Mekongga has been favored by farmers in Central Sulawesi for lesser loss of yield, and thus, could have a higher production compared to the new high yielding varieties introduced such as Inpari 9, Inpari 24, Inpari 30, and Inpari 36. Furthermore, Mekongga is also more resistant to pests and diseases. The finding in this study is similar to[16] who have seen the difficulties in replacing the old improved varieties of wheat in spite of its susceptibility to rust and diseases since the old improved varieties of wheat have a higher productivity in the normal years and established seeds and marketing system.

On the other hand, IAARD has produced many new high yielding varieties. There are varieties that are tolerant to pests and diseases and able to produce higher yields. For examples are Inpari 9 Elo and Inpari 36 that are tolerant to tungro disease with a potential yield of 9.3 tonnes/ha; Inpari 15 Parahiyangan tolerant to 033 blast disease with a potential yield 7.5 tonnes/ha, and Inpari 28 Kerinci tolerant to leaf blight pathotype IIIs with a potential yield of 9.5 tonnes/ha. IAARD is not only produced lowland rice varieties but also upland rice varieties namely Inpago 4, Inpago, 5, Inpago 6, Inpago 8, and Inpago Lipigo 4 with potential yield ranging between 6.2 and 8.4 tonnes/ha. These upland rice varieties are generally tolerant to blast which is the main disease of upland rice varieties and tolerant to aluminum poisoning which is the main problem of acid dry land. IAARD also produces Inpari 29 Rendaman dan Inpari 30 Ciherang Sub 1 that could be developed on flood-prone irrigated rice fields with yield potential of 9.5 tonnes/ha and 9.6 tonnes/ha. Inpari 42 , inpari 43 are the varieties which are tolerant to leafhoppers and dry. Inpara 4 and Inpara 5 are 
suitable for tidal swamps, shallow swamp areas and flood-prone rice fields. Inpara 4 and Inpara 5 could live in the water (puddle) for 14 days in the vegetative growth phase with yield potential 7.6 tonnes/ha and 7.2 tonnes/ha. The varieties also tolerant to HDB pathotype IV and VIII, and could be developed in shallow lowland swamps and flood-prone rice fields.

According to the interview and observation, as well as secondary data collected, it could be concluded that farmers in Central Sulawesi have a higher preferences towards varieties that have higher productivity and are resistant to drought, pests and diseases. The idea is supported by [11] through her study on farmers' preferences on high yielding varieties in Donggala, Central Sulawesi. [11] found that farmers have seen high productivity and resistance to pests and diseases as the first and second characteristics of rice varieties that should be existed before they decide to adopt. [16] also found high productivity and production as the main reason for farmers to adopt new high yielding varieties. As mentioned by [7], crop varieties with high capacity to yield will have a better opportunity of being adopted as well as being used intesively by farmers. This is reasonable since higher yield of crop will lead to the increasing marginal returns to investmet in seed and substantially higher income [7]. Therefore, Central Sulawesi AIAT should introduce new varieties of rice that are able to produce higher than the old improved varieties or local varieties. To disseminate new high yielding varieties, cooperation between the Central Sulawesi AIAT and the extension agents has become important. As [9] mentioned, the transfer of rice technology should be done in a packaged, from the preparation, cultivation, until post harvest, and marketing. To maintain the availability and accesibility of new high yielding varieties introduced, it is also suggested for Central Sulawesi AIAT to train farmers on how to produce high quality seeds of the new high yielding varieties.

\section{Conclusion}

Farmers in Central Sulawesi still use high yielding varieties introduced many years ago and local varieties. The highest high yielding varieties used by farmers in Central Sulawesi was Ciherang (70.74\%), followed by Mekongga (46.24\%), and Cisantana (39.32\%). Local varieties that mostly used by farmers in Central Sulawesi are Lombi-lombi, Paresina, Maraya, Tidore, and Pulu Lonu. Farmers still used those varieties since the varieties have a higher productivity and are resistant to drought, pest, and diseases. By referring to the information, farmers in Central Sulawesi tend to prefer new high yielding varieties with high production. In the long-run, it is also important to train farmers to become certified breeders. Hence, they could be able to produce new HYV preferred by farmers and to guarantee the sustainability of new HYV production in Central Sulawesi.

The authors gratefully acknowledge the support of Central Sulawesi Assessment Institute for Agricultural Technology for funding this research.

\section{References}

1. BPS Provinsi Sulawesi Tengah Sulawesi Tengah Province in Figures (Palu, Sulawesi Tengah: BPS Provinsi Sulawesi Tengah, 2020)

2. P. Sasmita, A. Jamil, Satoto, A. Guswara, Suharna, Rahmini and D.D. Handoko Deskripsi Varietas Unggul Baru Padi (Inbrida Padi Sawah Irigasi (INPARI) Hibrida Padi (HIPA) Inbrida Padi Gogo (INPAGO) Inbrida Padi Rawa (INPARA) (Sukamandi, Jawa Barat: Balitpa, 2019) 84 pp

3. A. Girma and A. Amanuel Int. J. Res. 5 338-56 (2017)

4. R.U. Onyeneke African J. Agric. Res. 12 888-96 (2017) 
5. A. Hagos and L. Zemedu Sci. Technol. Arts Res. J. 4 221-8 (2015)

6. A.H. Mesfin and Zemedu L Rice Sci. 25 350-6 (2018)

7. Y.L. Idrisa, B.O. Ogunbameru and M.C. Madukwe Greener J. Agric. Sci. 2 037-45 (2012)

8. M. Chekene and T. Chancellor J. Agric. Ext. 1921 (2015)

9. O.A. Abiola, S. Mad Nasir, R. Alias and A. Ismail International J. Agric. Sci. Vet. Med. 4 38-52 (2016)

10. Y. Gecho and N.K. Punjabi Raj. J. Extn. Edu 1-9 (2011)

11. H.S.P. Rahayu Widyariset 15 293-300 (2012)

12. K.B. Andri and N. Pangarsa Int. J. Agric. Syst. 4121 (2016)

13. [Syahri and R.U. Somantri J. Litbang Pertan. 35 25-36 (2016)

14. F. Palobo, M.K. Rumbarar and B.M.W. Tiro Int. J. Agric. Innov. Res. 6 2319-1473 (2018)

15. A.S. Romdon, Komalawati and Harwanto IOP Conf. Ser. Earth Environ. Sci. 518 (2020)

16. K.D. Joshi, A.U. Rehman, G. Ullah, M.F. Nazir, M. Zahara, J. Akhtar, M. Khan, A. Baloch, J. Khokhar, E. Ellahi, A. Khan, M. Suleman and M. Imtiaz J. Crop Improv. 31 608-27 (2017) 